\title{
Molaria (Euarthropoda) from the Sirius Passet Lagerstätte (Cambrian Series 2, Stage 3) of North Greenland
}

JOHN S. PEEL

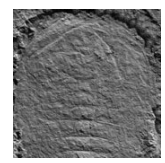

\begin{abstract}
A second species of the characteristic Burgess Shale euarthropod Molaria Walcott, 1912 is described from the Sirius Passet Lagerstätte of North Greenland, thus extending its range from Cambrian Series 3 (Stage 5) back into Series 2 (Stage 3). Molaria steini sp. nov. differs from the type species, $M$. spinifera Walcott, 1912, in having 9 trunk tergites and lacking an elongate connecting segment between the trunk and the jointed telson. Exopod setal fringes are similar to those in the artiopod Emeraldella Walcott, 1912 from the Burgess Shale but other details of limbs remain obscure. $\bullet$ Key words: Cambrian, euarthropod, Sirius Passet, Lagerstätte, Greenland.
\end{abstract}

PEEL, J.S. 2017. Molaria (Euarthropoda) from the Sirius Passet Lagerstätte (Cambrian Series 2, Stage 3) of North Greenland. Bulletin of Geosciences 92(2), 133-142 (4 figures). Czech Geological Survey, Prague, ISSN 1214-1119. Manuscript received January 19, 2017; accepted in revised form May 26, 2017; published online June 23, 2017; issued June 30, 2017.

John S. Peel, Department of Earth Sciences (Palaeobiology), Uppsala University, Villavägen 16, SE-75236 Uppsala, Sweden; john.peel@pal.uu.se

Few localities provide us with as much insight into life in the Cambrian as the lagerstätten of the Burgess Shale in western Canada, Chengjiang in South China and Sirius Passet in North Greenland. However, despite their similar geological settings (Ineson \& Peel 2011), the Burgess Shale Lagerstätte (Cambrian Series 3, Stage 5) and the Sirius Passet Lagerstätte (Cambrian Series 2, Series 3) lack common arthropod genera other than Isoxys Walcott, 1890, although this is represented by different species (Williams et al. 1996, García-Bellido et al. 2009b). Isoxys is also the only arthropod genus common to the Sirius Passet Lagerstätte, the contemporaneous Chengjiang Lagerstätte of South China, and the Emu Bay Shale Lagerstätte of South Australia (Shu et al. 1995, Vannier \& Chen 2000, Hou et al. 2004, García-Bellido et al. 2009a, Fu et al. 2011, Paterson et al. 2015), although Stein et al. (2010) questioned whether all the species assigned to the genus belonged therein.

This paper improves comparison between the Burgess Shale and Sirius Passet biotas in describing a new species of Molaria Walcott, 1912 from Sirius Passet: Molaria steini sp. nov. (Figs 1-4). It represents only the second species to be attributed to a genus originally described from the Burgess Shale (Walcott 1912, Whittington 1981). Whittington (1981) noted over a hundred specimens of the type species, Molaria spinifera Walcott, 1912, from the Burgess Shale, but it is a relatively rare component of an assemblage yielding more than 200,000 specimens to museum collections in the National Museum of Natural History, Washington D.C., and the Royal Ontario Museum, Toronto. Caron et al. (2014) also reported Molaria spinifera from the Stephen Formation at Marble Canyon. Molaria steini sp. nov. is also uncommon, with only about 30 specimens known from the Sirius Passet Lagerstätte.

\section{Sirius Passet Lagerstätte}

The geological setting of the Sirius Passet Lagerstätte was described by Ineson \& Peel (2011) and Peel \& Ineson (2011a, b). Fossils occur in dark mudstones of the Buen Formation (Cambrian Series 2, Stage 3) in a transitional regime between its southern shelf expression and a northern trough succession. This Transitional Buen Formation accumulated immediately offshore from the steep scarp margin of an underlying, relict, carbonate platform (Portfjeld Formation) which was transgressed by the Buen Formation as the Franklinian Basin expanded (Higgins et al. 1991, Ineson \& Peel 1997). Most specimens were collected from talus accumulating immediately below a small crag of the formation (Peel \& Ineson 2011b, locality 1).

Fossil arthropods from the Sirius Passet Lagerstätte vary in length of the shield exclusive antennulae from $5 \mathrm{~mm}$ to more than $210 \mathrm{~mm}$ in Arthroaspis bergstroemi Stein, 
Budd, Peel \& Harper, 2013. Molaria steini is one of the smallest species, with the shield attaining a length of $20 \mathrm{~mm}$, to which may be added a $10 \mathrm{~mm}$ long telson. Claims in the literature (e.g. Minelli et al. 2013, p. 400) and on websites that specimens of Kiisortoqia soperi Stein, 2010 from Sirius Passet exceed $50 \mathrm{~cm}$ in length are based on the unfortunate reiteration of an obvious typographical error, with the true size range (23.4-53.4 $\mathrm{mm}$ and not 234-534 mm) being clearly visible in an adjacent histogram in the original publication (Stein 2010, p. 481, fig. 3). However, specimens of the lobopodian Pambdelurion Budd, 1997 from Sirius Passet may reach $46 \mathrm{~cm}$ in length (Vinther et al. 2016, p. 847). While partial growth series may be present, early ontogentic stages of arthropods have not been described from Sirius Passet. Neither have trace fossils that can be attributed to the activities of arthropods been recognized, but see Peel (2010) and Mangano et al. (2012).

Weakly mineralized organisms from the Burgess Shale Lagerstätte are mainly preserved as reflective films (Butterfield et al. 2007, Orr \& Kearns 2011, Gaines et al. 2012) but equivalent fossils from the Sirius Passet Lagerstätte are usually preserved in mudstone as flattened impressions that often maintain slight relief. Sirius Passet taxa with originally calcareous exoskeletons often retain high relief, the latter including the trilobite Buenellus higginsi Blaker, 1988, the armoured Halkieria evangelista Conway Morris \& Peel, 1995 and hyoliths (Peel 2010), as well as individual spicules from the diverse assemblage of sponges (Botting et al. 2015, Botting \& Peel 2016). Burgess Shale style preservation occurs at certain horizons at Sirius Passet (Vinther et al. 2011a, b), but a characteristic feature of many, but not all, arthropods and lobopodians from the Sirius Passet Lagerstätte is the three-dimensional preservation of the axis and digestive tract resulting from early post-mortem mineralization (Budd 1997, 2011; Vannier et al. 2014; Strang et al. 2016a; Peel 2017).

The preservational and diagenetic history of the Sirius Passet Lagerstätte is complex (Budd 1997, 1998, 2011; Conway Morris \& Peel 2008; Peel et al. 2013; Stein et al. 2013; Vannier et al. 2014; Strang et al. 2016a, b; Peel 2017) and excellent preservation was not extended equally to all. Each of the 10-15 arthropod taxa currently known has its own preservational history, with internal axial structures and distal portions of antennulae and other limbs particularly subject to variable preservation. Thus, Isoxys volucris Williams, Siveter \& Peel, 1996 is represented by hundreds of specimen of relatively uniform size (10-20 mm) but only three specimens with preserved soft parts are known (Stein et al. 2010). The nevadiid trilobite Buenellus higginsi is also known from hundreds of mainly complete shields varying in size from $20 \mathrm{~mm}$ to $100 \mathrm{~mm}$, but smaller holaspids or meraspids have not been recorded (Babcock \& Peel 2007). Early diagenetic mineralization of the digestive tract in the glabella and axial lobe of the thorax is common in B. higginsi (Blaker \& Peel 1997, Babcock \& Peel 2007), but only 7 known specimens preserve traces of antennulae, and other limbs are not known

Sirius Passet arthropods often show three-dimensional preservation of the digestive tract and axial area but appendages usually become obscure distally (Budd 2011). The three-dimensional preservation indicates early post-mortem mineralization that may reflect the mediating role of endogenous bacteria in phosphatization within the digestive system, but phosphorus and calcium also may have been stored within the digestive tract during life (Watabe 1989, Butterfield 2002, Butler et al. 2015, Zacaï et al. 2016, Strang et al. 2016a, Peel 2017). Vannier et al. (2014) identified phosphates just in the mineralized digestive tract of the lobopod Pambdelurion while silicified muscle fibres were reported by Budd $(1998,2011)$ in various arthropods, and by Conway Morris \& Peel (2008) in the polychaete Phragmochaeta canicularis Conway Morris \& Peel, 2008.

More than 1700 specimens of the isopygous arthropod Campanamuta mantonae Budd, 2011 are known from Sirius Passet. Many display three-dimensional differential preservation of soft parts in the axial region, and muscle fibres, the gut and paired digestive glands have been recognized (Budd 2011). Strang et al. (2016a) noted that the fossilized gut in Campanamuta mantonae contains a high proportion of calcium phosphate, while muscle fibres are preserved in silica, as previously noted by Budd (2011).

Available specimens of Molaria steini sp. nov. preserve the fully articulated shield with telson; a hypostome may be visible. Early diagenetic internal mineralization of the axial region gives an impression of trilobation. Antennulae are poorly preserved just as stubs adjacent to the shield. Other appendages are known only from setae occurring mainly beneath the trunk tergites and interpreted as fringes to exopod articles; the endopods are not known.

\section{Material and methods}

Peel \& Ineson (2011a) recounted the discovery and exploration of the Sirius Passet Lagersätte. Expeditions to Sirius Passet in 1989, 1991, 1994 and 2006 supported by the Geological Survey of Greenland produced a collection of more than 10,000 fossil specimens, in addition to the small original collections made by A.K. Higgins, N.C. Davies and N.J. Soper during GGU field work in 1984-85 (Conway Morris et al. 1987). The collection is now deposited in the Geological Museum, Copenhagen, a part of the Natural History Museum of Denmark. Geologists from the University of Copenhagen visited Sirius Passet in 2009 and 2011, but no specimens from these collections are described herein. 
All specimens were blackened with colloidal carbon and whitened with ammonium chloride sublimate prior to photography using low angle, linear, non-flickering light sources. Images were captured on a variety of digital cameras and prepared for publication in Adobe Photoshop CS4. Some images were 'stacked' using Helicon Focus.

Institutional abbreviations. - GGU indicates a sample made under the auspices of Grønlands Geologiske Undersøgelse (Geological Survey of Greenland), now a part of the Geological Survey of Denmark and Greenland. Type and figured specimens are deposited in the type collection of the Geological Museum (MGUH prefix), a part of the Natural History Museum of Denmark.

\section{Systematic palaeontology}

Euarthropoda sensu Walossek, 1999

Artiopoda sensu Stein et al. 2011

\section{Genus Molaria Walcott, 1912}

Type species. - Molaria spinifera Walcott, 1912; from the Burgess Shale Lagerstätte (Cambrian Series 3, Stage 5) of British Columbia.

Other species. - Molaria steini sp. nov. from the Sirius Passet Lagerstätte (Cambrian Series 2, Stage 3) of North Greenland.

Discussion. - Whittington (1981) gave a detailed description of the type species Molaria spinifera, discussing previous work notably by Simonetta (1964) and Simonetta \& Delle Cave (1975). Simonetta \& Delle Cave (1991) accepted most of Whittington's (1981) findings but remained unconvinced about the supposed jointing of the long telson. Placement of Molaria within Artiopoda follows Stein et al. (2011) who suggested a close relationship with Emeraldella Walcott, 1912. However, Stein et al. (2011) noted that filiform antennulae, one of the diagnostic characters of Artiopoda, were not documented in the type species Molaria spinifera. Although imperfectly preserved, the short section of the left antennula in $M$. steini sp. nov. illustrated here (Fig. 3B) seems to allay this concern.

A weighted phylogenetic analysis by Stein et al. (2013, fig. 16A) grouped Molaria together with Retifacies Hou, Chen \& Lu, 1989 and Emeraldella Walcott, 1912 in an un-named clade (NN2) of Lamellipedia. Lists of aglaspid core taxa (Aglaspidida s.s.), aglaspid-like taxa and non-aglaspid taxa presented by Van Roy (2006, table 1) do not contain Molaria. Ortega-Hernández et al. (2013) proposed a clade Vicissicaudata to include the aglaspidid arthropods, xenopods (Emeraldella and Sidneyia Walcott, 1911) and cheloniellids; Molaria was not included in the analysis. Legg et al. (2013) grouped Molaria with Emeraldella within Xenopoda. Edgecombe et al. (2017) compared the phylogenetic analyses of Stein et al. (2013) and Ortega-Hernández et al. (2013) in describing a new early Cambrian aglaspid-like arthropod from South Australia.

\section{Molaria steini sp. nov.}

Figures 1-4

Holotype. - MGUH 31523 from GGU sample 340103 (Fig. 1B, D).

Paratypes. - MGUH 28757-28759 and MGUH 31524-31526 from GGU sample 340103.

Type horizon and locality. - Sirius Passet Lagerstätte, locality 1 of Peel \& Ineson (2011a); Transitional Buen Formation (Cambrian Series 2, Stage 3) of Ineson \& Peel (2011).

Etymology. - For Martin Stein, in recognition of his arthropod studies, and with thanks for our Sirius Passet adventure.

Material. - Specimens 969, 3577, 4069, 4535, 4751, 4851 and about 20 additional specimens from GGU sample 340103 .

Diagnosis. - A species of Molaria with 9 trunk tergites, the posteriormost of which articulates directly with the transversely jointed telson; an elongate, distinct, sub-cylindrical segment intermediate between the trunk tergites and the telson in the type species $M$. spinifera is seemingly not present.

Description. - The combined head shield and trunk is typically $12-15 \mathrm{~mm}$ long. In the largest observed specimen (Fig. 1B; the holotype), the head shield and trunk attain a total length of $20 \mathrm{~mm}$, with the telson about $10 \mathrm{~mm}$ long. In plan view the body is ovoid, narrowing posteriorly, with the maximum width of just more than two thirds of length achieved at tergite 2 . The head shield is almost semicircular in outline with angular posterolateral corners and an almost straight posterior border. Its length is up to almost half of the maximum width but may appear less due to crushing witnessed by the prominent comarginal wrinkles. It is seemingly without trilobation or inflation of the axial area, although the central area may be unaffected by crushing. Eyes are not known.

The hypostome is $2.7 \mathrm{~mm}$ long (sag.) and $1.3 \mathrm{~mm}$ wide (Figs 2A, C, 4A); as preserved it is not attached to the anterior margin of the head shield but the sharply angled anterior surface suggests that it was in life. It is spindle shaped with its greatest width at mid-length, from which shallowly 


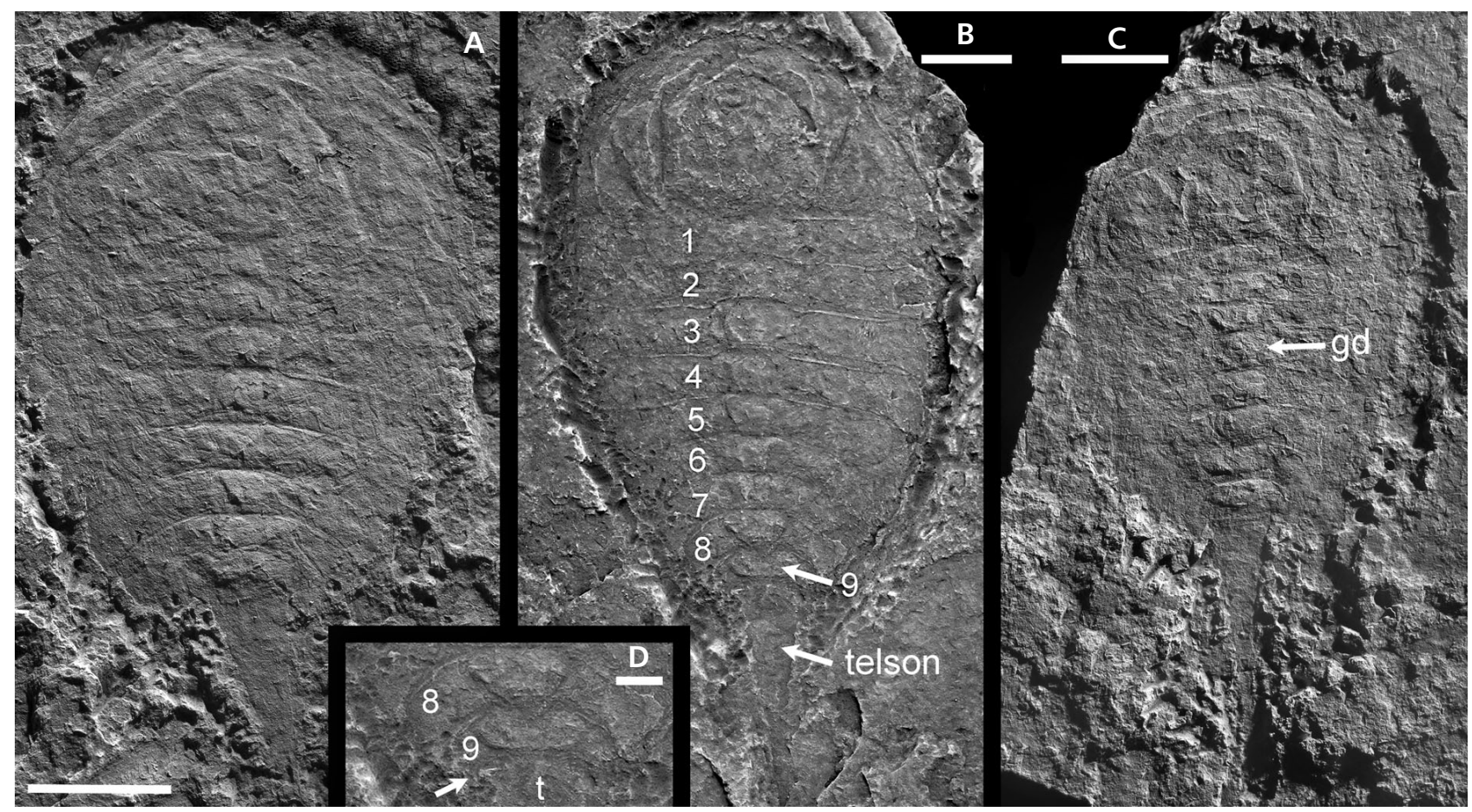

Figure 1. Molaria steini sp. nov., Sirius Passet Lagerstätte, Transitional Buen Formation (Cambrian Series 2, Stage 3), Peary Land, North Greenland. - A - MGUH 31524, paratype. $・$ B, D - MGUH 31523, holotype, with detail of $9^{\text {th }}$ tergite (D), see also Fig. 4B; tergites are numbered 1-9, t indicates telson, arrow in D locates tergopleural spine on $9^{\text {th }}$ tergite. $\bullet$ C - MGUH 31525 , paratype, gd indicates gut diverticula within $4^{\text {th }}$ tergite. Scale bars: $3 \mathrm{~mm}$, except D $(1 \mathrm{~mm})$.

concave sides converge anteriorly prior to terminating abruptly at the narrow truncated anterior surface. The antennulae (Figs 2A, 4A) emerge from near the central point (sag.) of these concave sides. Posteriorly of the median point of greatest width, the lateral surfaces initially slope obliquely in towards the axis before turning abruptly parallel to the axis. The anterior half of the hypostome is ornamented by two converging longitudinal ridges or folds, while the posterior section shows two transverse channels (Fig. 4A).

The trunk in most specimens consists of 8 tergites with tergopleurae which decrease slightly in length (sag.) towards the posterior (Fig. 1B), but a 9th similar tergite is present in the holotype and one other specimen, apparently a reflection of greater size. Internal mineralization of the axial area of tergites creates the impression of dorsal trilobation (Fig. 1A-C) but tergite sutures are not usually deflected when crossing this axis. Tergite 1 is straight but curvature of the tergites increases towards the posterior such that tergite 8 is strongly crescentic, convex anteriorly (Figs 1B, 2D). Tergite 1 attains its greatest width at the angular posterolateral corners but, with increasing curvature of the tergites, the corners become produced into short spines and maximum tergite width is near the suture with the previous tergite (Fig. 2D). Overlap between tergites is about one tenth of tergite length (sag.) and does not appear to increase significantly away from the axis towards the lateral margins. A cord-like transverse ridge is present near the anterior margin of tergites $1-5$ in the holotype (Fig. 1B) and is preserved as a groove on tergites 1-6 in Fig. 2B, C; the ridge is weakly expressed or absent in the axial region.

A $9^{\text {th }}$ tergite present in the holotype (Figs $1 \mathrm{~B}, \mathrm{D}, 4 \mathrm{~B}$ ), the largest available specimen, has a transverse width of only half of the $8^{\text {th }}$ tergite. Its presence is most clearly indicated by the sub-lenticular mineralized axial structure which occupies almost the full width of the tergite near its anterior margin and is clearly delimited from the telson. A strongly curved posterolateral tergopleural spine is preserved on the left side of the tergite (arrow in Figs 1D, 4B) and its posterior margin is marked by a transverse cord.

The gut is not preserved in available material but most specimens preserve raised axial swellings within each tergite which may include gut diverticula (Figs 1A-C, 4B). These vary in shape from rhomboidal, with the transverse broadest surface anterior, to sub-lenticular, and are often delimited from each other by deep grooves (Fig. 1A, B). Collectively, these gut diverticula form an axial structure which gives the appearance of trilobation to the trunk; similar structures have not been observed beneath the head shield.

The telson attains at least one third of the total length of the organism but its finely tapered extremity is often 


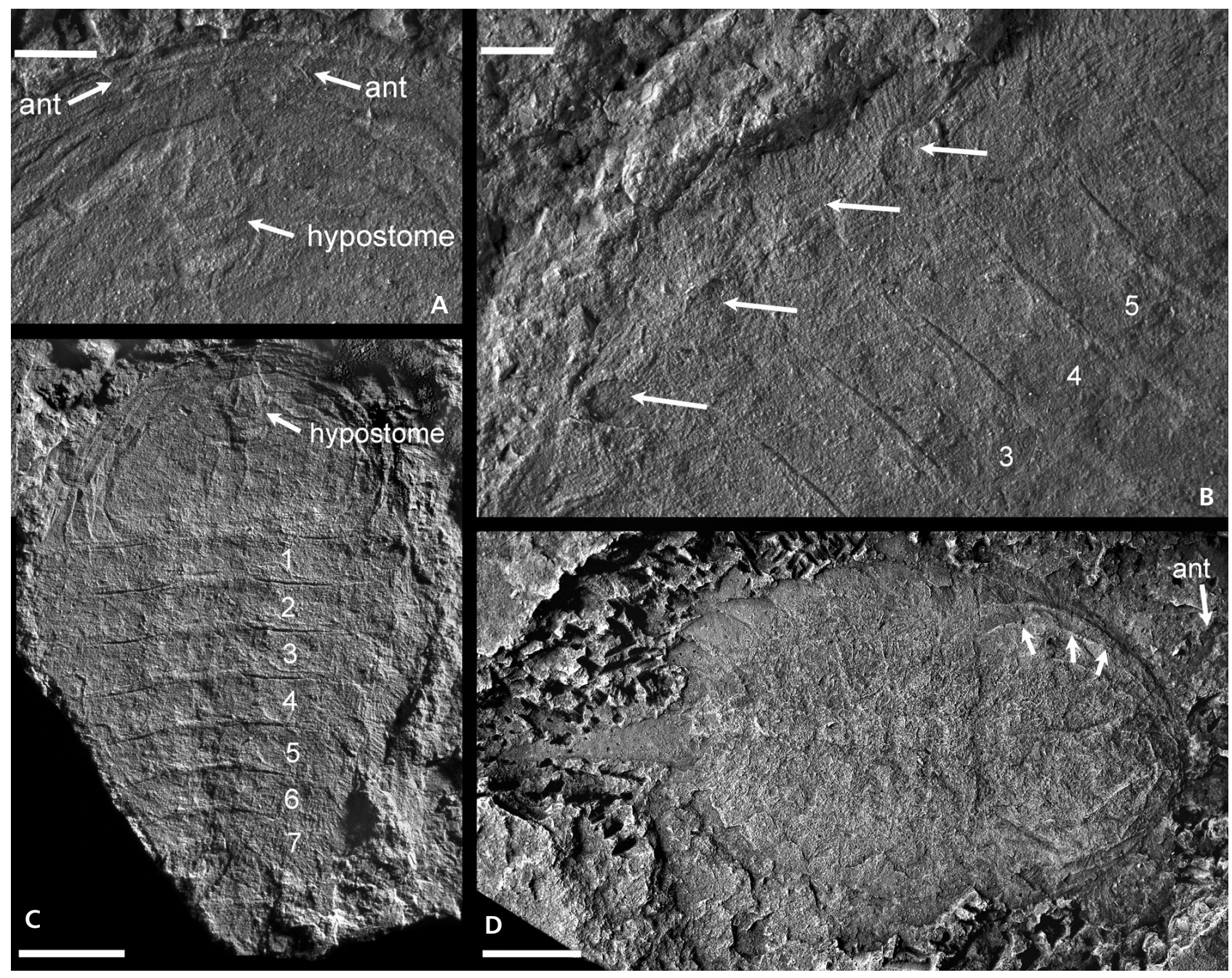

Figure 2. Molaria steini sp. nov., Sirius Passet Lagerstätte, Transitional Buen Formation (Cambrian Series 2, Stage 3), Peary Land, North Greenland. - A - MGUH 31526, paratype, detail of C, undersurface showing hypostome and base of antennules (ant). B - MGUH 31526, paratype, detail of C, showing setal fringes around distal articles of exopods (arrowed) and tergites 3-5. $\bullet$ - MGUH 31526, paratype, under surface showing tergites 1-7, hypostome (detail in A and Fig. 4A), and setal fringes of exopods on right side (detail in B). D - MGUH 28759, paratype, with arrows indicating setal bunches. Scale bars: $1 \mathrm{~mm}(\mathrm{~A}, \mathrm{~B})$ and $3 \mathrm{~mm}(\mathrm{C}, \mathrm{D})$.

obscure; maximum width occurs at its articulation with the preceding tergite. The sides of the telson are initially straight, forming an angle of about 15 degrees, but become shallowly concave as it narrows distally (Fig. 1A-C). Articulation within the telson is indicated by weakly expressed transverse furrows, although these are not usually consistently visible in specimens as preserved and their recognition may be obscured by transverse compression fractures. In the holotype (Fig. 1B) such transverse furrows are more closely spaced than the length (sag.) of the trunk tergites.

While traces of limbs are common, their preservation is incomplete. The antennulae emerge from beneath the anterolateral surfaces of the hypostoma (Figs 2A, 4A) but their length is not known. Their maximum observed proximal width is about $0.6 \mathrm{~mm}$, with about 5 articles per $\mathrm{mm}$
(Fig. 3B). Distal parts of the tergopleurae are often underlain by swathes of setae of exopodal origin (Figs 2B, $\mathrm{C}, 3 \mathrm{~A})$. Most commonly, these setae radiate from rounded, spatulate lobes interpreted as the terminal article of the exopods (arrows in Fig. 2B). In one specimen broad ridges suggesting limbs, with relatively long and straight setae, correspond to tergites 1-5 (arrows a in Fig. 3A) and suggest the proximal portion of exopods. Setae radiating from the supposed distal articles of these exopods are preserved in the posterior portion of the same specimen (arrows $b$ in Fig. 3A). Endopods have not been recognized but likely contribute to the broad ridges noted above. In one specimen three separate tufts of slightly diverging setae on the left posterolateral margin of the head shield (arrows in Fig. 2D) indicate the presence of at least three limbs posterior to the antennule. 


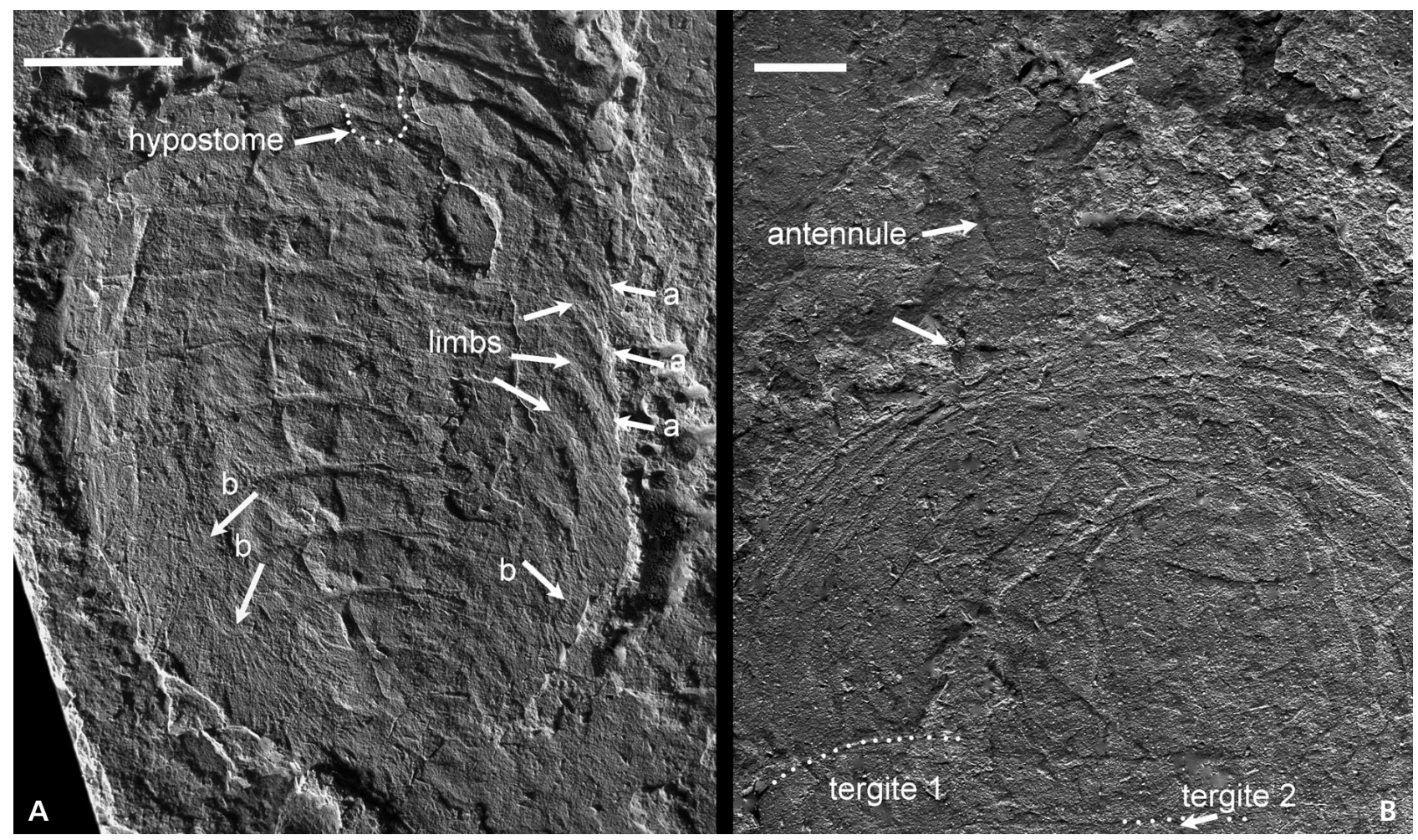

Figure 3. Molaria steini sp. nov., Sirius Passet Lagerstätte, Transitional Buen Formation (Cambrian Series 2, Stage 3), Peary Land, North Greenland. - A - MGUH 28757, paratype, with proximal exopod setae (arrows a) and radiating setal fringes around distal article of exopods (arrows b). posterior margin of hypostome indicated. $\bullet$ B - MGUH 28758, paratype, showing detail of antennule (arrows). Scale bars: 3 mm (A) and 1 mm (B).

\section{Discussion}

Most available specimens of Molaria steini preserve only 8 tergites in the trunk but 9 tergites are present in the holotype, the largest available specimen, suggesting that the difference is ontogenetic.

In its overall proportions, the shield of Molaria steini closely resembles the aglaspid Glypharthrus Raasch, 1939 but the latter has 11 tergites in the trunk, compared to 8 or 9 in M. steini, and well developed eyes on the head shield (Hesselbo 1992; Ortega-Hernández et al. 2013). Neither eyes on the head shield, nor the postero-ventral plates characteristic of aglaspidids, are recorded in M. steini.

Emeraldella differs from Molaria steini in the greater number of tergites in the trunk. Stein \& Selden (2012) reported 12 tergites in the type species Emeraldella brocki Walcott, 1912 from the Burgess Shale Lagerstätte, of which the elongate $12^{\text {th }}$ tergite had much reduced tergopleurae. Only 11 tergites are present in E. brutoni Stein, Church \& Robison, 2011 from the Wheeler Shale of Utah. As with M. spinifera, but unlike M. steini, E. brocki develops an elongate segment between the last regular tergite and the telson. This elongate segment carries caudal flaps which have been considered homologous to the diagnostic ventral plates of true aglaspids, although that homology was discounted by Ortega-Hernández et al. (2013).

Retifacies has 10 tergites in the trunk and a jointed telson, but differs from Molaria steini in possessing a prominent tail shield (Hou \& Bergström 1997, fig. 50). Eozetetes gemmelli Edgecombe, Paterson and GarcíaBellido, 2017, from the Emu Bay Shale of South Australia has 18 tergites in the broad trunk, compared to the 8 or 9 of M. steini, and the telson is apparently not jointed. A short tergite lying posterior of the $18^{\text {th }}$ tergite, articulating with the telson, is not seen in M. steini.

The trunk in Kwanyinaspis maotianshanensis from the Chengjiang Lagerstätte, South China has 12 tergites, the most posterior 7 of which have strongly pointed tergopleural spines, and was reported to have ventral eyes beneath the head shield (Zhang \& Shu, 2005). It also differs in that the hypostome expands broadly towards the anterior (Ortega-Hernández et al. 2013, fig. 1), whereas the hypostome of M. steini narrows anteriorly (Fig. 2A, C).

On account of the long telson, specimens from the Sirius Passet Lagerstätte assigned to Molaria steini are unlikely to be confused with contemporaneous arthropod taxa (Blaker 1988; Budd 1995, 1999, 2011; Babcock \& Peel 2007; Lagebro et al. 2009; Peel \& Stein 2009; Stein 2010; Stein et al. 2013; Peel 2017). Buenaspis Budd, 1999 is of 
similar size, and its head shield and tergites are similar to the anterior portion of $M$. steini, not least with regard to the concentric crushing pattern of the flattened head shields. It is readily distinguished, however, by its isopygous form, with the large, sub-circular tail shield displaying a uniformly convex posterior margin without spines (Budd 1999). Additionally, only 6 tergites are present in Buenaspis, compared to 8 or 9 in M. steini.

Whittington (1981) stated that the type species Molaria spinifera ranged in length from 8-26 mm (excluding the telson). About thirty specimens of $M$. steini are known from Sirius Passet, although the present description is based on 11 selected specimens; the length of these varies between 12 and $20 \mathrm{~mm}$, excluding the telson. Specimens of M. steini are wider (width 70-75\% of length exclusive of telson) than M. spinifera, where the width is about $60 \%$ of length. While a $9^{\text {th }}$ tergite is present in the holotype of M. steini (Figs 1B, D, 4B) and one other specimen, most specimens preserve only 8 tergites, as is also the case in all specimens of $M$. spinifera described by Whittington (1981). Antennulae are not well preserved in either species but those described by Whittington (1981) in the type species are minute, less robust than the preserved remains in M. steini (Figs 2A, D, 3B). The telson is much longer in M. spinifera than in M. steini.

The slender hypostome of Molaria steini narrows towards the anterior (Figs 2A, 4A) in contrast to the broad hypostome of Emeraldella brocki which expands widely anteriorly (Stein \& Selden 2012, figs 11a, 12). Whittington (1981) does not appear to have observed a hypostome in M. spinifera. Hypostomes of similar proportions to that of M. steini were described in Emucaris fava Paterson, Edgecombe, García-Bellido, Jago \& Gehling, 2010 and Kangacaris zhangi Paterson, Edgecombe, García-Bellido, Jago \& Gehling, 2010 from the Emu Bay Shale, but they are detached from the anterior margin of the head shield and develop prominent transverse spines from the anterior margin. A hypostome is not described in Campanamuta mantonae from the Sirius Passet although a poorly defined, spindle-shaped structure visible in some specimens (Budd 2011, figs 16, 17) resembles the hypostome of M. steini, but is much more deeply located within the head shield. In Arthroaspis bergstroemi the hypostoma is rectangular to oval, proportionally wider than in M. steini (Stein et al. 2013).

The principal difference between the two species of Molaria concerns the presence in Molaria spinifera of an elongate, sub-cylindrical, segment between the posteriormost trunk tergite and the long telson (telson spine of Whittington 1981, fig. 73). Such a connecting segment is not recognized in $M$. steini where the telson appears to articulate with the $8^{\text {th }}$ tergite (Figs $1 \mathrm{~A}, \mathrm{C}, 2 \mathrm{D}$ ) or with the $9^{\text {th }}$ tergite when present, as in the holotype (Fig. 1B, D). Whittington (1981, p. 341) noted specimens of M. spinifera
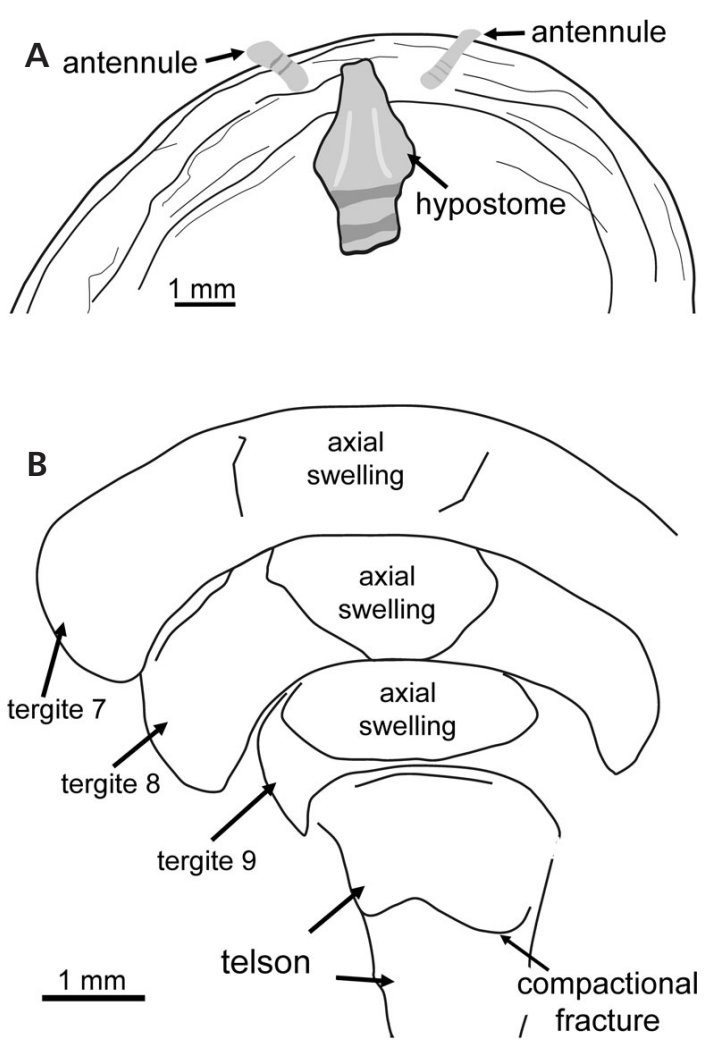

Figure 4. Molaria steini sp. nov., Sirius Passet Lagerstätte, Transitional Buen Formation (Cambrian Series 2, Stage 3), Peary Land, North Greenland. • A - MGUH 31526, paratype, drawing of undersurface of head shield showing hypostome and base of antennules. Anteriorly, the hypostome is ornamented by two converging ridges or folds, while the posterior section shows two transverse channels. • B - MGUH 31523, holotype, drawing of trunk-telson transition showing $9^{\text {th }}$ tergite articulating with telson.

where the connecting segment had been forced diagenetically under the posterior trunk tergites and therefore not visible, but there is no evidence of this having occurred in available specimens of $M$. steini.

Stein \& Selden (2012) discussed previous interpretations of the segment that occurs between the $11^{\text {th }}$ trunk tergite and the telson in Emeraldella brocki Walcott, 1912 from the Burgess Shale. They noted that this segment was more elongate than more anterior tergites and had much reduced tergopleurae, but considered it to be a $12^{\text {th }}$ trunk tergite. In overall shape this $12^{\text {th }}$ tergite of E. brocki resembles the connecting segment of Molaria spinifera illustrated by Whittington (1981, fig. 73) but the latter lacks lateral spines. The $9^{\text {th }}$ tergite of $M$. steini, visible in the holotype (Fig. 1B, D), differs from both these elongate elements in maintaining the proportions of the previous tergite (more than twice as wide as long) and carrying strongly incurved tergopleural spines. Its interpretation as a $9^{\text {th }}$ trunk tergite rather than the connecting segment appears secure. Since the holotype is the largest available specimen of M. steini, it is likely that the presence of this $9^{\text {th }}$ tergite is a reflection of size. 
Biramous limb structure is not demonstrated conclusively in Molaria steini since neither endopods or exopod axes have been recognized in available, incompletely preserved material. It is likely, however, that both branches contribute to the broad ridges preserved on the right side of MGUH 28757 (Fig. 3A). Similar traces of limbs through the shield are visible in Naraoia compacta Walcott, 1912 (Whittington 1971 with Haug \& Haug 2016) from the Burgess Shale. In a model of exopod structure such as the reconstruction of the exopod branch of limbs of Emeraldella brocki made by Stein \& Selden (2012, fig. 9), this might imply that the setae forming the setal fringes were more robust than the articles and the absence of exopod and endopod branches is a preservational artifact. However, the distribution of the setae in Molaria steini agrees with the reconstruction made by Stein \& Selden (2012) despite the absence of recognized limb branches. Lamellae of Stein \& Selden (2012, fig. 9) diverging from article 1 of the exopod in E. brocki can be compared to long, straight setae in M. steini (arrows a in Fig. 3A), whereas the spatulate termination of article 3 in $E$. brocki is bordered by radiating setae closely similar to those present in M. steini (arrows in Fig. 2B; arrows b in Fig. 3A).

An alternative interpretation follows the elegant reinterpretation of trunk appendages in Naraoia compacta Walcott, 1912 proposed by Haug \& Haug (2016, fig. 2a) in specimens of similar size to Molarai steini. The exopod in $N$. compacta carries a series of stacked, overlapping, oval flaps bordered with fine setae. Only the uppermost flap is seen in its entire oval form, with a radial fringe of setae. On account of overlap, just the proximal lateral margin is visible of flaps located lower in the stack, creating the impression of a proximal series of lamellae and a distal oval flap (Haug \& Haug 2016, fig. 2a). Thus the lamellae of Stein \& Selden (2012, fig. 9) would represent the edges of proximal flaps. In M. steini (Fig. 2B, arrows) oval flaps with radiating setal fringes are clearly associated with each tergite in MGUH 31526. Similar flaps with radial setal fringes are also visible posteriorly in MGUH 28757 (Fig. 3A, arrows b), but the setae are longer and much more robust than in Naraoia. The parallel structures located laterally in more anterior parts of the trunk (Fig. 3A, arrows a) appear to be setae rather than the margins of flaps, but this does not exclude their association with stacked exopod flaps, as envisaged by Haug \& Haug (2016).

\section{Acknowledgements}

I am particularly grateful to Martin Stein (Copenhagen) for sharing his insight into fossils from the Sirius Passet Lagerstätte, and for generously providing many of the current photographs. The Geological Survey of Greenland (GGU), now the Geological Survey of Denmark and Greenland (GEUS, Copenhagen), and the former Danish Polarcenter, Copenhagen, established a logistic framework that supported expeditions to Sirius Passet in 1989, 1991, 1994 and 2006. Grants to support field work from the Carlsberg Foundation, Copenhagen, National Geographic Society, Washington D.C. (to Simon Conway Morris, Cambridge, U.K.) and the Danish Natural Science Research Council (to GEUS via Jon R. Ineson, Copenhagen) are acknowledged with thanks, as is financial support from the Swedish Research Council (Vetenskapsrådet). Reviews for the journal by Joachim T. Haug (Munich) and Javier Ortega-Hernández (Cambridge) are gratefully acknowledged.

\section{References}

BABCOCK, L.E. \& PeEL, J.S. 2007. Palaeobiology, taphonomy, and stratigraphic significance of the trilobite Buenellus from the Sirius Passet Biota, Cambrian of North Greenland. Memoirs of the Association of Australasian Palaeontologists 34, 401-418.

BlaKer, M.R. 1988. A new genus of nevadiid trilobite from the Buen Formation (Early Cambrian) of Peary Land, central North Greenland. Grønlands Geologiske Undersøgelse Rapport 137, 33-41.

Blaker, M.R. \& Peel, J.S. 1997. Lower Cambrian trilobites from North Greenland. Meddelelser om Grønland, Geoscience 35, $145 \mathrm{pp}$.

Botting, J. \& Peel, J.S. 2016. Early Cambrian sponges of the Sirius Passet Biota, North Greenland. Papers in Palaeontology 2, 463-467. DOI 10.1002/spp2.1048

Botting, J., Cardenas, P. \& Peel, J.S. 2015. A crown-group demosponge from the early Cambrian Sirius Passet Biota, North Greenland. Palaeontology 58, 35-43. DOI 10.1111/pala.12133

BuDD, G.E. 1995. Kleptothule rasmusseni gen et sp. nov.: an ?olenellinid-like trilobite from the Sirius Passet fauna (Buen Formation, Lower Cambrian, North Greenland). Transactions of the Royal Society of Edinburgh, Earth Science 86, 1-12. DOI 10.1017/S0263593300002121

BudD, G.E. 1997. Stem group arthropods from the Lower Cambrian Sirius Passet fauna of North Greenland, 125-138. In Fortey, R.A. \& Thomas, A.H. (eds), Arthropod Relationships. The Systematics Association Special Volume 55.

BuDD, G.E. 1998. Arthropod body-plan evolution in the Cambrian with an example from anomalocaridid muscle. Lethaia 31, 197-210. DOI 10.1111/j.1502-3931.1998.tb00508.x

BuDD, G.E. 1999. A nektaspid arthropod from the early Cambrian Sirius Passet fauna, with a description of retrodeformation, based on functional morphology. Palaeontology 42, 99-122. DOI 10.1111/1475-4983.00064

BudD, G.E. 2011. Campanamuta mantonae gen. et sp. nov., an exceptionally preserved arthropod from the Sirius Passet Fauna (Buen Formation, lower Cambrian, North Greenland). Journal of Systematic Palaeontology 9, 217-260. DOI 10.1080/14772019.2010.492644

Butler, A.D., Cunningham, J.A., Budd, G.E. \& Donoghue, P.C.J. 2015. Experimental taphonomy of Artemia reveals the role of endogenous microbes in mediating decay and fossilization. Proceedings of the Royal Society of London B 282, 1-10. DOI 10.1098/rspb.2015.0476

BUTTERFIELD, N.J. 2002. Leanchoilia guts and the interpretation 
of three-dimensional structures in Burgess Shale-type fossils. Paleobiology 28, 155-171.

DOI 10.1666/0094-8373(2002)028<0155:LGATIO>2.0.CO;2

Butterfield, N.J., Balthasar, U., \& Wilson, L.A. 2007 Fossil diagenesis in the Burgess Shale. Palaeontology 50, 537-543. DOI 10.1111/j.1475-4983.2007.00656.x

Caron, J.-B., Gaines, R.R., Aria, C., Mángano, M.G. \& Streng, M. 2014. A new phyllopod bed-like assemblage from the Burgess Shale of the Canadian Rockies. Nature communications 5:3210,1-6. DOI 10.1038/ncomms4210

Conway Morris, S. \& Peel, J.S. 1995. Articulated halkieriids from the Lower Cambrian of of North Greenland and their role in early protostome evolution. Philosophical Transactions of the Royal Society of London B 347, 305-358.

DOI 10.1098/rstb.1995.0029

Conway Morris, S. \& Peel, J.S. 2008. The earliest annelids: Lower Cambrian polychaetes from the Sirius Passet Lagerstätte, Peary Land, North Greenland. Acta Palaeontologica Polonica 53, 137-148. DOI 10.4202/app.2008.0110

Conway Morris, S., Peel, J.S., Higgins, A.K., Soper, N.J. \& DAvis, N.C. 1987. A Burgess Shale-like fauna from the Lower Cambrian of Greenland. Nature 326, 181-183.

DOI 10.1038/326181a0

Edgecombe, G.D., Paterson, J.R. \& García-Bellido, D.C. 2017. A new aglaspid-like euarthropod from the lower Cambrian Emu Bay Shale of South Australia. Geological Magazine 184, 87-95. DOI 10.1017/S0016756815001053

Fu, D., Zhang, X. \& Shu, D. 2011. Soft anatomy of the Early Cambrian arthropod Isoxys curvirostratus from the Chengjiang biota of South China with a discussion of the origination of great appendages. Acta Palaeontologica Polonica 56, 843-852. DOI 10.4202/app.2010.0090

Gaines, R.R., Hammarlund, E.U., Hou, X., Qi, C., Gabbott, S.E., Zhao, Y., Peng, J. \& CANField, D.E. 2012. Mechanism for Burgess Shale-type preservation. Proceedings of the $\mathrm{Na}$ tional Academy of Sciences of the United States of America 109, 5180-5184. DOI 10.1073/pnas.1111784109

García-Bellido, D., Paterson, J., Edgecombe, G., Jago, J., GeHLing, J. \& LEE, M. 2009a. The bivalved arthropods Isoxys and Tuzoia with soft part preservation from the Lower Cambrian Emu Bay Shale (Kangaroo Island, Australia). Palaeontology 52, 1221-1241.

DOI 10.1111/j.1475-4983.2009.00914.x

García-Bellido, D., Vannier, J. \& Collins, D. 2009b. Soft-part preservation in two species of the arthropod Isoxys from the middle Cambrian Burgess Shale of British Columbia. Acta Palaeontologica Polonica 54, 699-712. DOI 10.4202/app.2009.0024

Haug, C. \& Haug, J.T. 2016. New insights into the appendage morphology of the Cambrian trilobite-like arthropod Naraoia compacta. Bulletin of Geosciences 91, 221-227.

DOI 10.3140/bull.geosci.1573

Hesselbo, S.P., 1992. Aglaspida (Arthropoda) from the Upper Cambrian of Wisconsin. Journal of Paleontology 66, 885-923. DOI 10.1017/S0022336000021016

Higgins, A.K., Ineson, J.R., Peel, J.S., Surlyk, F. \& SønderHOLM, M. 1991. Lower Palaeozoic Franklinian Basin of North Greenland. Grønlands Geologiske Undersøgelse Bulletin 160, 71-139.

Hou, X. \& Bergström, J. 1997. Arthropods of the Lower Cambrian Chengjiang fauna, southwest China. Fossils \& Strata 45, 1-116.
Hou, X., Aldridge, R.J., Bergström, J., Siveter, D.J., Siveter, D.J., \& FenG, X.H. 2004. The Cambrian Fossils of Chengjiang, China. The Flowering of Early Animal Life. 233 pp. Blackwell Science Ltd., Malden, Massachusetts.

Hou, X., Chen, J. \& Lu, H. 1989. Early Cambrian new arthropods from Chengjiang, Yunnan. Acta Palaeontologica Sinica 28, 42-57. [in Chinese with English summary]

InEson, J.R., \& PeEL, J.S. 1997. Cambrian shelf stratigraphy of North Greenland. Geology of Greenland Survey Bulletin 173, $1-120$.

Ineson, J.R., \& PeEL, J.S. 2011. Geological and depositional setting of the Sirius Passet Lagerstätte (early Cambrian), North Greenland. Canadian Journal of Earth Sciences 48, 1259-1281. DOI 10.1139/e11-018

Lagebro, L., Stein, M. \& Peel, J.S. 2009. A new ?lamellipedian arthropod from the early Cambrian Sirius Passet Fauna of North Greenland. Journal of Paleontology 83, 820-825.

DOI 10.1666/09-011.1

LegG, D.A., Sutton, M.D. \& Edgecombe, G.D. 2013. Arthropod fossil data increase congruence of morphological and molecular phylogenies. Nature communications 4:2485, 1-7. DOI 10.1038/ncomms3485

Mangano, M.G., Bromley, R.G., Harper, D.A.T., Nielsen, A.T., Sмith, M.P. \& Vinther, J. 2012. Nonbiomineralized carapaces in Cambrian seafloor landscapes (Sirius Passet, Greenland): opening a new window into early Phanerozoic benthic ecology. Geology 40, 519-522.

DOI 10.1130/G32853.1

Minelli, A., Boxshall, G. \& Fusco, G. (eds) 2013. Arthropod biology and evolution: molecules, development, morphology. 532 pp. Springer-Verlag, Berlin \& Heidelberg.

ORR, P.J. \& KeARns, S.L. 2011 X-ray microanalysis of Burgess Shale and similarly preserved fossils, 271-299. In LAFLAMME, M., Schiffbauer, J.D. \& Dornbos, S.Q. (eds) Numerical approaches to the evaluation of fossils and ancient ecosystems. Springer Science+Business Media, Dordrecht, Heidelberg, London, New York.

Ortega-Hernández, J., LegG, D.A. \& Braddy, S.J. 2013. The phylogeny of aglaspidid arthropods and the internal relationships within Artiopoda. Cladistics 29, 15-45. DOI 10.1111/j.1096-0031.2012.00413.x

Paterson, J.R., Edgecombe, G.D., García-Bellido, D.C., Jago, J. \& Gehling, J.G. 2010. Nektaspid arthropods from the lower Cambrian Emu Bay Shale Lagerstätte, South Australia, with a reassessment of lamellipedian relationships. Palaeontology 53, 377-402. DOI 10.1111/j.1475-4983.2010.00932.x

Paterson, J.R., García-Bellido, D.C., Jago, J., Gehling, J.G., Lee, M.S.Y. \& Edgecombe, G.D. 2015. The Emu Bay Shale Konservat-Lagerstätte: a view of Cambrian life from East Gondwana. Journal of the Geological Society 173, 1-11. DOI 10.1144/jgs2015-083

PeEL, J.S. 2010. Articulated hyoliths and other fossils from the Sirius Passet Lagerstätte (early Cambrian) of North Greenland. Bulletin of Geosciences 85, 385-394. DOI 10.3140/bull.geosci.1207

Peel, J.S. 2017. Mineralized gutfills from the Sirius Passet Lagerstätte (Cambrian Series 2) of North Greenland. GFF 139, 83-91. DOI 10.1080/11035897.2016.1260051

Peel, J.S. \& Ineson, J.R. 2011a. The Sirius Passet Lagerstätte (early Cambrian) of North Greenland. Palaeontographica Canadiana 31, 109-118.

Peel, J.S. \& Ineson, J.R. 2011b. The extent of the Sirius Passet 
Lagerstätte (early Cambrian) of North Greenland. Bulletin of Geoscience 86, 535-543. DOI 10.3140/bull.geosci.1269

Peel, J.S. \& Stein, M. 2009. A new arthropod from the lower Cambrian Sirius Passet Fossil-Lagerstätte of North Greenland. Bulletin of Geosciences 84, 625-630.

DOI 10.3140/bull.geosci.1158

Peel, J.S., Stein, M. \& Kristensen, R.M. 2013. Life cycle and morphology of a Cambrian stem-lineage loriciferan. PLoS ONE 8(8):e73583, 1-20.

DOI 10.1371/journal.pone.0073583

RAASCH, G.O. 1939. Cambrian Merostomata. Geological Society of America Special Paper 16, 1-146.

Shu, D., Zhang, X. \& GeYer, G. 1995. Anatomy and systematic affinities of the Lower Cambrian bivalved arthropod Isoxys auritus. Alcheringa 19, 333-342. DOI 10.1080/03115519508619512

SimonetTA, A.M. 1964. Osservazioni sugli artropodi non trilobiti della 'Burgess Shale' (Cambriano medio). III Contributo. Monitore zoológico italiano 72, 215-231.

Simonetta, A.M. \& Delle Cave, L. 1975. The Cambrian non trilobite arthropods from the Burgess Shale of British Columbia. A study of their comparative morphology, taxonomy and evolutionary significance. Palaeontographica italica 69 , $1-37$.

Simonetta, A.M. \& Delle Cave, L. 1991. Early Palaeozoic arthropods and problems of arthropod phylogeny; with some notes on taxa of doubtful affinities, 189-244. In SimONETTA, A.M. \& Conway Morris, S. (eds) The early evolution of Metazoa and the significance of problematic taxa. Cambridge University Press, Cambridge.

Stein, M. 2010. A new Cambrian arthropod from Greenland. Zoological Journal of the Linnean Society 158, 477-500. DOI 10.1111/j.1096-3642.2009.00562.x

Stein, M., Budd, G.E., Peel, J.S. \& Harper, D.A.T. 2013. Arthroaspis n. gen., a common element of the Sirius Passet Lagerstätte (Cambrian, North Greenland), sheds light on trilobite ancestry. BMC Evolutionary Biology 2013 13(99), 1-34. DOI 10.1186/1471-2148-13-99

Stein, M., Church, S.B. \& Robison, R.A. 2011. A new Cambrian arthropod, Emeraldella brutoni, from Utah. Palaeontological Contributions 3, 1-9.

Stein, M., Peel, J.S., Siveter, D.J., \& Williams, M. 2010. Isoxys (Arthropoda) with preserved soft anatomy from the Sirius Passet Lagerstätte, lower Cambrian of North Greenland. Lethaia 43, 258-265. DOI 10.1111/j.1502-3931.2009.00189.x

Stein, M. \& Selden, P.A. 2012. A restudy of the Burgess Shale (Cambrian) arthropod Emeraldella brocki and a reassessment of its affinities. Journal of Systematic Palaeontology 10, 361-383. DOI 10.1080/14772019.2011.566634

Strang, K.M., Armstrong, H.A. \& Harper, D.A.T. 2016a. Minerals in the gut: scoping a Cambrian digestive system. Royal Society Open Science 3, 160420, 1-9. DOI 10.1098/rsos.160420

Strang, K.M., Armstrong, H.A., Harper, D.A.T. \& TraBucho-AlEXANDRE, J.P. 2016b. The Sirius Passet Lagerstätte: silica death masking opens the window on the earliest mat ground community of the Cambrian explosion. Lethaia 49, 631-643. DOI 10.1111/let.12174

VAN Roy, P. 2006. An aglaspidid arthropod from the Upper Ordovician of Morocco with remarks on the affinities and limita- tions of Aglaspidida. Transactions of the Royal Society of Edinburgh: Earth Sciences 96, 327-350.

VANNIER, J. \& CHEN, J. 2000. The Early Cambrian colonization of pelagic niches exemplified by Isoxys (Arthropoda). Lethaia 33, 295-311. DOI 10.1080/002411600750053862

Vannier Liu, J., Lerosey-Aubril, R., Vinther, J. \& Daley, A.C. 2014. Sophisticated digestive systems in early Arthropods. Nature communications 5:3641, 1-9.

DOI 10.1038/ncomms4641

Vinther, J., Eibye-Jacobsen, D. \& Harper, D.A.T. 2011a. An Early Cambrian stem polychaete with pygidial cirri. Biology letters 7, 929-932. DOI 10.1098/rsbl.2011.0592

Vinther, J., Porras, L., Young, F.J., Budd, G.E. \& Edgecombe, G.D. 2016. The mouth apparatus of the Cambrian gilled lobopodian Pambdelurion whittingtoni. Palaeontology 59, 841-849. DOI 10.1111/pala.12256

Vinther, J., SMith, M.P. \& HARPer, D.A.T. 2011b. Vetulicolians from the Lower Cambrian Sirius Passet Lagerstätte, North Greenland, and the polarity of morphological characteristics in basal deuterostomes. Palaeontology 54, 711-719. DOI 10.1111/j.1475-4983.2011.01034.x

WalcotT, C.D. 1890. The fauna of the Lower Cambrian or Olenellus Zone. Reports of the U.S. Geological Survey 10, 509-763.

WalcotT, C.D. 1911. Cambrian geology and palaeontology II. Middle Cambrian Merostomata. Smithsonian Miscellaneous Collection 57, 17-40.

WalcotT, C.D. 1912. Middle Cambrian Branchiopoda, Malacostraca, Trilobita, and Merostomata. Cambrian Geology and Paleontology, II. Smithsonian Miscellaneous Collection $57,145-228$.

WALOSSEK, D. 1999. On the Cambrian diversity of Crustacea, 3-27. In Schram, F.R. \& von Vaupel Klein, J.C. (eds) Crustaceans and the Biodiversity Crisis, Proceedings of the Fourth International Crustacean Congress, Amsterdam, The Netherlands, July 20-24, 1998 vol. 1. Brill Academic Publishers, Leiden.

WAtABE, N. 1989. Calcium phosphate structures in invertebrates and protozoans, 35-44. In CARTER, J.G. (ed.) Skeletal biomineralization: patterns, processes and evolutionary trends. Van Nostrand Reinhold, New York; Chapman \& Hall, London.

Whittington, H.B. 1971. The Middle Cambrian trilobite Naraoia, Burgess Shale, British Columbia. Philosophical Transactions of the Royal Society of London B 280, 409-443. DOI 10.1098/rstb.1977.0117

Whittington, H.B. 1981. Rare arthropods from the Burgess Shale, Middle Cambrian, British Columbia. Philosophical Transactions of the Royal Society of London B 292, 329-357. DOI 10.1098/rstb.1981.0033

Williams, M., Siveter, D.J., \& Peel, J.S. 1996. Isoxys (Arthropoda) from the Early Cambrian Sirius Passet Lagerstätte, North Greenland. Journal of Paleontology 70, 947-954. DOI 10.1017/S0022336000038646

Zacaï, A., VAnnier, J. \& Lerosey-Aubril, R. 2016. Reconstructing the diet of a 505-million-year-old arthropod: Sidneyia inexpectans from the Burgess Shale fauna. Arthropod Structure and Development 45, 200-220. DOI 10.1016/j.asd.2015.09.003

Zhang, X. \& SHU, D. 2005. A new arthropod from the Chengjiang Lagerstätte, Early Cambrian, southern China. Alcheringa 29, 185-194. DOI 10.1080/03115510508619300 